\section{(6) OPEN ACCESS}

\title{
Dominant B cell receptor clones in peripheral blood predict onset of arthritis in individuals at risk for rheumatoid arthritis
}

\author{
Paul P Tak, ${ }^{1}$ Marieke E Doorenspleet, ${ }^{2,3}$ Maria J H de Hair, ${ }^{1}$ Paul L' arenbeen ${ }^{3}$ \\ Marian $\mathrm{H}$ van Beers-Tas, ${ }^{4}$ Antoine $\mathrm{H}$ C van Kampen, ${ }^{5}$ Dirkjan va chaardenbul. \\ Danielle M Gerlag, ${ }^{1}$ Frank Baas, ${ }^{3}$ Niek de Vries ${ }^{2}$

\section{ABSTRACT} \\ the developy it of syn ruial inflà may be
}

Handling editor Tore K Kvien

- Additional material is published online only. To view please visit the journal online (http://dx.doi.org/10.1136/ annrheumdis-2017-211351).

'Department of Clinical Immunology and Rheumatology, Academic Medical Center, University of Amsterdam, Amsterdam, The Netherlands ${ }^{2}$ Amsterdam Rheumatology and Immunology Center, Academic Medical Center, Amsterdam, The Netherlands

${ }^{3}$ Department of Genome Analysis, Academic Medical Center, Amsterdam, The Netherlands

${ }^{4}$ Amsterdam Rheumatology and Immunology Center, Reade, Amsterdam, The Netherlands ${ }^{5}$ Department of Clinical Epidemiology, Biostatistics and Bioinformatics, Academic Medical Center, Amsterdam, The Netherlands

Correspondence to Niek de Vries, Department of Clinical Immunology and Rheumatology, Academic Medical Center, University of Amsterdam, Amsterdam 1100 $D E$, The Netherlands: n.devries@amc.uva.nl

Received 21 February Revised 15 July 2017 Accepted 18 July 2017 Published Online First 8 August $20^{1}$

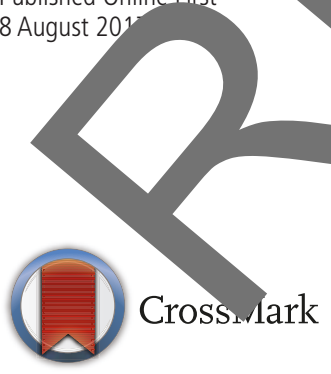

To cite: Tak PP,

Doorenspleet ME,

de Hair MJH, et al.

Ann Rheum Dis

2017:76:1924-1930.
Background The onset of seropositive rheumatoid arthritis (RA) is preceded by the presence of specific autoantibodies in the absence of synovial inflammation. Only a subset of these at-risk individuals will develop clinical disease. This impedes efforts to implement early interventions that may prevent onset of clinically manifest disease. Here we analyse whether clonal changes in the $\mathrm{B}$ cell receptor (BCR) repertoire can reliably predict onset of signs and symptoms.

Methods In a prospective cohort study in 21 individuals at risk for RA based on the presence autoantibodies, the $B C R$ repertoire of paired $p e$ heral blood and synovial tissue samples was analysed next-generation $B C R$ sequencing. $B C R$ clones that expanded beyond $0.5 \%$ of the tota labelled dominant. The relative risk in, of arthritis was assessed using the pres ce of $\geq 0$ $B C R$ clones as cut-off. Findings in per, ral $b$ od were validated in an independent prospective 50 at-risk individuals. Bac test coho individuals in the validation $\mathrm{co}^{\prime}$, were $\mathrm{c}$ sidered $\mathrm{po}$ ve if peripheral blood study entr nowed $\geq 5 \mathrm{~d}$, rinant BCR clones.

Findings th in validation cohort, the presence $\geq 5$ domina. $R$ clones in peripheral blood was s. cantly associate afte olu (validation coh RR 6.3, 95\% Cl 2.7 $\left.t, 5, p<1 \times \quad{ }^{4}\right)$. Even when adjusted for a recently described clinica. diction rule the association remained intact ( $R R, \quad 95 \% \mathrm{Cl} 1.2$ to $20, \mathrm{p}=0.024$ ). Wher individuals developed arthritis, dominant $B C R$ Clo disappeared from peripheral blood and appeared ynovial tis suggesting a direct role of these clones n disease $r$ rogenesis.

Interpr cion Dominant BCR clones in peripheral $d$ dict onset of clinical signs and symptoms of RA 、at-risk individuals with high accuracy. Our data cuggest that during onset of RA these clones shift from eripheral blood to the target tissue.

\section{INTRODUCTION}

Rheumatoid arthritis (RA) is a prototypic chronic autoimmune disease with partly unknown aetiology. Clinically manifest arthritis due to synovial inflammation is the hallmark feature of RA. However, it is not the first sign of disease, as patients may already experience arthralgia and preceded the prese of disease-specific autoantibodies. This ation is miniscent of that in se $\mathrm{al}$ oth amune-me ated inflammatory dis es. ${ }^{4-7}$

specific autoa dies, IgM-rheumatoid actor $F$ ) and/or anticitrullinated protein antibodies ( 4 ), can be present up to 15 years before onset of disc 189 Towards the onset of clinically evident arthritis ne ACPA repertoire may broaden due to epitope spreading, ${ }^{10} 11$ and levels of inflammato cytokines and chemokines may increase. ${ }^{12} 13$ Altho $h$ the presence of ACPA is highly specific for $\mathrm{R}$ and may precede its onset, only $20 \%$ of the au ntibody positive subjects will develop arthritis thin 4 years. ${ }^{15}$

The presence of these autoantibodies preceding the development of RA clearly points to a role for $\mathrm{B}$ cells and plasma cells in the pathogenesis of RA. The pathogenic role of $B$ cells in established RA is supported by the known association with autoantibodies, ${ }^{16}$ marked infiltration of the synovium by B cells and plasma cells, ${ }^{17}$ the production of autoantibodies in the synovial compartment ${ }^{18}$ and the response to $\mathrm{B}$ cell-depleting therapy. ${ }^{19}$ Consistent with this notion, $\mathrm{B}$-cell receptor (BCR) repertoire analysis showed that dominant clones were found in the inflamed synovial tissue of patients with established RA. ${ }^{20}$

We hypothesised that dominant clones may be detected by BCR sequencing in the peripheral blood during the preclinical phase of RA. This might help predict which at-risk individuals will develop arthritis over time. We tested this hypothesis analysing paired peripheral blood and synovial tissue samples from individuals at risk for developing RA in a prospective cohort study. We found that the presence of dominant peripheral blood BCR clones can predict future onset of RA, and we validated these findings in an independent cohort. Of interest, during the transition to clinically manifest arthritis the BCR clones were not traceable in peripheral blood anymore, but they were found in synovial tissue as highly dominant clones, pointing to a shift of BCR clones to the synovial compartment. The observation that dominant peripheral blood BCR clones can predict future onset of disease may be relevant for other B cell-mediated autoimmune diseases as well. 
Table 1 Clinical characteristics of healthy controls, at-risk individuals who did not develop arthritis over time and at-risk individuals who developed arthritis. At-risk individuals have elevated titres for $\operatorname{lgM}-\mathrm{RF}$ (>12.5 kU/L) and/or anti-CCP (>25 kAU/L). Healthy individuals have low titres for $\operatorname{lgM}-\mathrm{RF}(\leq 12.5 \mathrm{kU} / \mathrm{L})$ and anti-CCP ( $\leq 25 \mathrm{kAU} / \mathrm{L})$

\begin{tabular}{|c|c|c|c|}
\hline & Healthy individuals $(n=10)$ & $\begin{array}{l}\text { At-risk individuals no arthritis } \\
\text { developed }(n=10)\end{array}$ & $\begin{array}{l}\text { At-risk individuals arthritis developed } \\
(\mathrm{n}=11)\end{array}$ \\
\hline Female sex, n (\%) & $7(70)$ & $5(50)$ & $7(64)$ \\
\hline Age, years, median (IQR) & $34(28-51)$ & $50(39-60)$ & $48(42-5$ \\
\hline Level low positive, $n(\%)^{*} \dagger$ & - & $6(86)$ & \\
\hline Level high positive, $n(\%)^{*} \dagger$ & - & $1(14)$ & \\
\hline IgM-RF/ACPA double positive, $n(\%)$ & - & $4(40)$ & \\
\hline ESR, median (IQR)§ & - & $3(2-23)$ & \\
\hline CRP, median (IQR)ף & $0.9(0.4-2.9)$ & $2.1(1.6-6.3)$ & \\
\hline 68TJC, median (IQR) & $0(0)$ & $2(0-7)$ & \\
\hline 66SJC, median (IQR) & $0(0)$ & $0(0)$ & \\
\hline $\begin{array}{l}\text { METHODS } \\
\text { Study subjects } \\
\text { Sixty-five consecutive indivi } \\
\text { for the development of RA } \\
\text { and/or ACPA (anti-CCP2 tes } \\
\text { tively followed (further deno } \\
\text { the } 65 \text { included individuals, } \\
\text { body positive at-risk individ } \\
\text { (median follow-up } 69 \text { (rang }\end{array}$ & 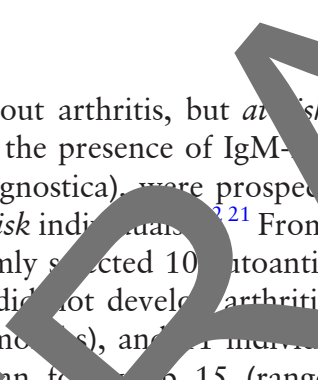 & $\begin{array}{l}\text { bes according to the m } \\
\text { novial biopsies, isolatio } \\
\text { linA synthesis were pe } \\
\text { ped arthritis was perform } \\
\text { lfilled the } 2010 \mathrm{ACR} / \mathrm{EL} \\
\text { itiation of treatment. }\end{array}$ & $\begin{array}{l}\text { stored in PAXGene Blood RNA } \\
\text { acturer's instructions (catalogue } \\
\text { a, the Netherlands). Storage of } \\
\text { nd quantification of RNA, and } \\
\text { med as described previously. } \\
\text { ividuals who subsequently devel- } \\
\text { on the same joint, after patients } \\
\text { R criteria for } \text { RA }^{22}{ }^{23} \text { and before }\end{array}$ \\
\hline
\end{tabular}
uals who did develop arthritis (m an to 15 (range 0-65) months) as test cohort. $\mathrm{P}$ individua of the latter group fulfilled the $2010 \mathrm{ACR} / \mathrm{E}^{\mathrm{T}}$ R criteria for $\mathrm{k}$ onset of arthritis, ${ }^{22}$ while two had $y$ ass arthritis at the moment of development of arthritis bu subsequ $\mathrm{did}$ fulfil RA criteria over time. In addition, autoantibody tive healthy individuals without any jo complaints were in ded as controls (clinical characteris of all thee groups described in table 1 and online supple entary ta $\$ 1$ ).

In total, 21 at indi als and healthy controls were included in this part study.

A valid ohort of sisting of 50 consecutively include divia s with el ACPA and/or IgM-RF without any s of arth is and at least 36 months follow-up (further det are dese During sequencing and bioinformatis alye ior dominant clones laboratory personnel was blinded inical data and outcome.

The coho studies were approved by the local medical ethical commit. of the Academic Medical Center/University of Amsterdam and MC Slotervaart Amsterdam, and all study subjects gave written informed consent.

Peripheral blood and synovial tissue sampling and processing In the 21 at-risk individuals of the test cohort, mini-arthroscopic synovial biopsy sampling was performed upon inclusion in a (non-arthritic) knee joint as previously described. ${ }^{25}$ Peripheral

\section{Linear amplification and next-generation sequencing (NGS)}

The linear amplification protocol has been extensively described before. ${ }^{26}$ Details are provided in the online supplementary methods. Samples were prepared for next-generation sequencing according to the manual for amplicon sequencing, and sequenced on a Roche Genome Sequencer FLX (Titanium platform). 10,000 $\mathrm{BCR}_{\text {heavy }}$ sequences were analysed for each peripheral blood sample and $7500 \mathrm{BCR}_{\text {heavy }}$ sequences for each synovial tissue sample. We use the term dominant BCR clone to denote clones whose unique BCR signals represent $\geq 0.5 \%$ of the repertoire, as described earlier. ${ }^{20}$

\section{Bioinformatics pipeline and data analysis}

The bioinformatics pipeline used to obtain the BCR sequences was described previously in detail ${ }^{27}$ and contains four modules: multiplex identifier sorting, identification of $\mathrm{V}$ and $\mathrm{J}$ gene segments, CDR3 detection and removal of artefacts. Immunoglobulin isotype homology was determined using the National Center for Biotechnology Information's open-access web tool Megablast and reference sequences for the human immunoglobulin heavy-chain constant regions, allowing a sequence homology $>97 \% .{ }^{28}$ Values are expressed as mean and SD or median and IQR range, according to criteria for (non-)parametric analysis. Differences between groups were analysed 

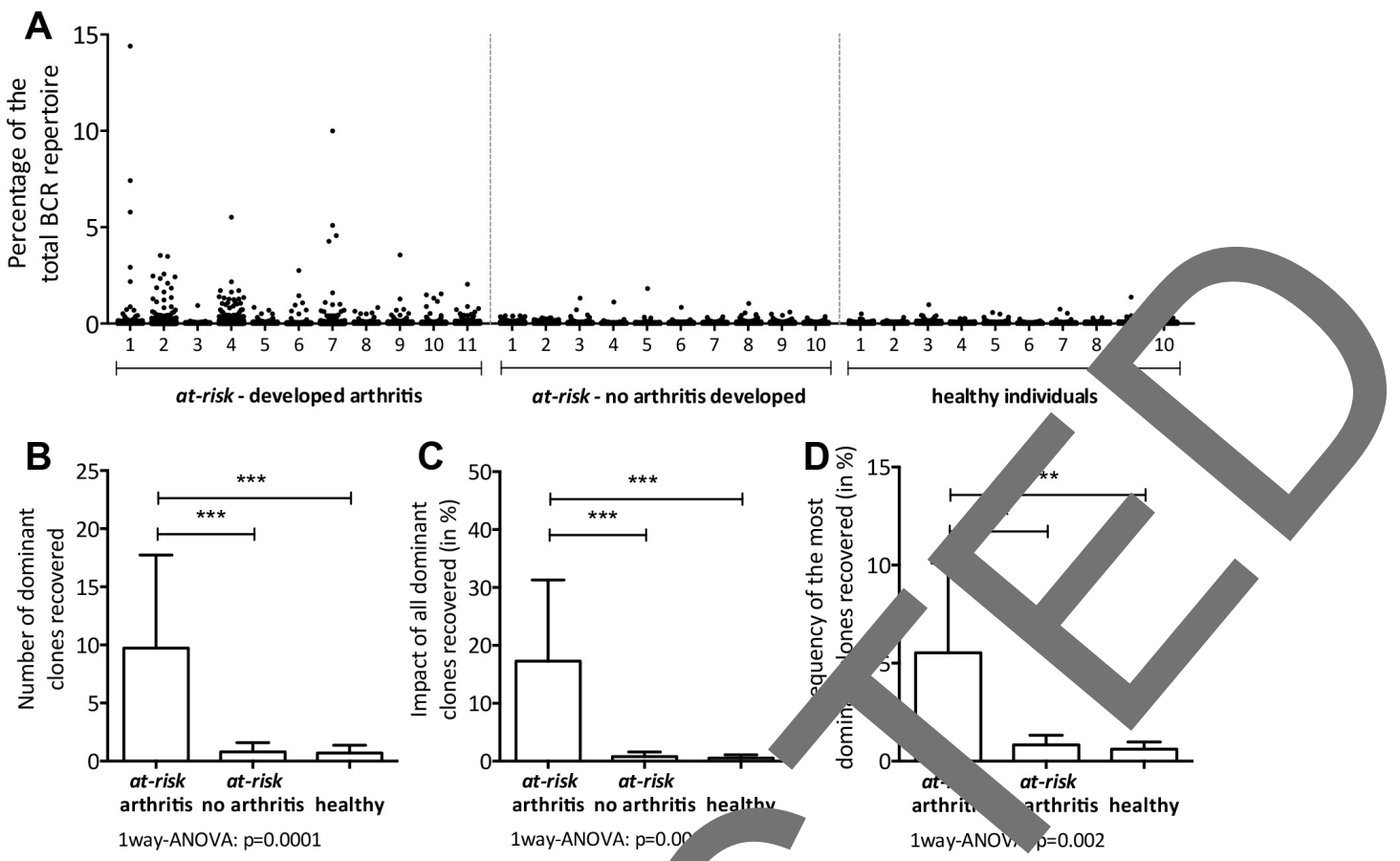

Figure 1 (A) Scatterplot of the BCR repertoire in peripheral blood of 11 at-ri Individuals who dryeloped arthritis (at-risk - developed arthritis), 10 at-risk individuals who did not develop arthritis (at-risk - no arthritis develc d) and 10 autoan represents one clone. The size of the clones is depicted as percentage of the to $\mathrm{BCR}_{\text {heavy }}$ sequence (clonal size $\geq 0.5 \%$ of the total repertoire), (C) the impact of all dominant clones bined and (D) risk individuals who developed arthritis (at-risk arthritis, $\mathrm{n}=11$ ) versus at-risk indivia and healthy individuals (healthy, $\mathrm{n}=10$ ). Bars show mean and $\mathrm{SD}_{\text {, }}$ $B C R, B$-cell receptor.

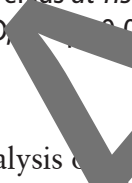

using Student's t-test, Mann-Whitney U test, one-wav analysis variance or $\chi^{2}$ test where appropriate. Receiv pu ng char acteristic (ROC) curves were used to deter me cut- values for the prediction of arthritis developm in the $t$ cohort. Logistic regression analysis was used to $\mathrm{r}_{\mathrm{i}} \mathrm{ct}$ the of high-throughput fingerprinting $\mathrm{d}$ qu on of BCR clones compared with an existir prediction del for the development of RA. ${ }^{24} \mathrm{GraphPa}$ ism software $h$ on 6 and PASW Statistics version $22 \mathrm{y}$ to perform the nalyses. p-values $<0.05$ were consid ed statis ${ }^{1 / v}$ significant.

\section{RESULTS}

Identification of de nant per'sheral blood BCR clones before onset of aritis

Based on earlier arva is that d inant BCR clones are present in the synovin sue durin anically manifest RA, we hypothesi these mig detectable in the peripheral bl befo developh of arthritis. Indeed, multiple domint BCR nes were derected in peripheral blood of all 11 ospectiv t-risk individuals who developed arthru ro the test cohort, as long as 66 months before the clinical of arthritis. In contrast, dominant BCR clones were nearly a noth in the 10 at-risk individuals who did not develop arthrit $d$ in the 10 healthy individuals (figure 1A). We observed that the number of dominant BCR clones, the impact of all dominant BCR clones combined (size of all dominant clones combined as percentage of the total repertoire) and the impact of the most dominant BCR clone were increased in at-risk individuals who developed arthritis during follow-up, compared with those who did not develop arthritis and healthy individuals (number of dominant clones mean 9.7 \pm 8.0 vs
$0.8 \pm 0.8$ vs $0.7 \pm 0.7$, respectively, $\mathrm{p}=0.001$ (figure $1 \mathrm{~B}$ ), impact of the dominant clones median $16.4 \%$ of the total repertoire, IQR $3.7 \%-33.7 \%$ vs $0.7 \%$ IQR $0 \%-1.7 \%$ vs $0.5 \%$ IQR $0 \%-1.1 \%$, respectively, $\mathrm{p}<0.0001$ (figure $1 \mathrm{C}$ ) and impact of the single most dominant clone mean $5.5 \% \pm 4.6 \%$ vs $0.7 \% \pm 0.7 \%$ vs $0.6 \% \pm 0.4 \%$, respectively, $\mathrm{p}<0.0003$ (figure $1 \mathrm{D})$ ). Subsequently, we analysed synovial tissue biopsies in at-risk individuals obtained during the preclinical phase, but these samples contained BCR mRNA levels that were too low to allow next-generation sequenting (NGS). The low BCR mRNA levels in the synovium during the preclinical stage of the disease are explained by the absence of B cell infiltration as demonstrated before using immunohistochemistry. ${ }^{3}$

Collectively, these observations demonstrate that dominant BCR clones are readily detectable in peripheral blood during the preclinical phase in all at-risk individuals who will develop RA after follow-up, but not in those who did not.

\section{The presence of dominant BCR clones predicts future arthritis development}

Having shown that the presence of BCR clones can be detected in peripheral blood in all at-risk individuals who will subsequently develop RA, in some cases after several years, we next aimed to develop a biomarker that can be used to identify individuals who have a high risk of developing arthritis in the short term. Such patients might be treated in the at-risk phase to prevent onset of arthritis. ${ }^{29}$ A clinically relevant follow-up period of 36 months was chosen to evaluate arthritis development. This time period may carry a risk high enough to justify preventive pharmacological intervention, while being short enough to infer urgency for treatment. 

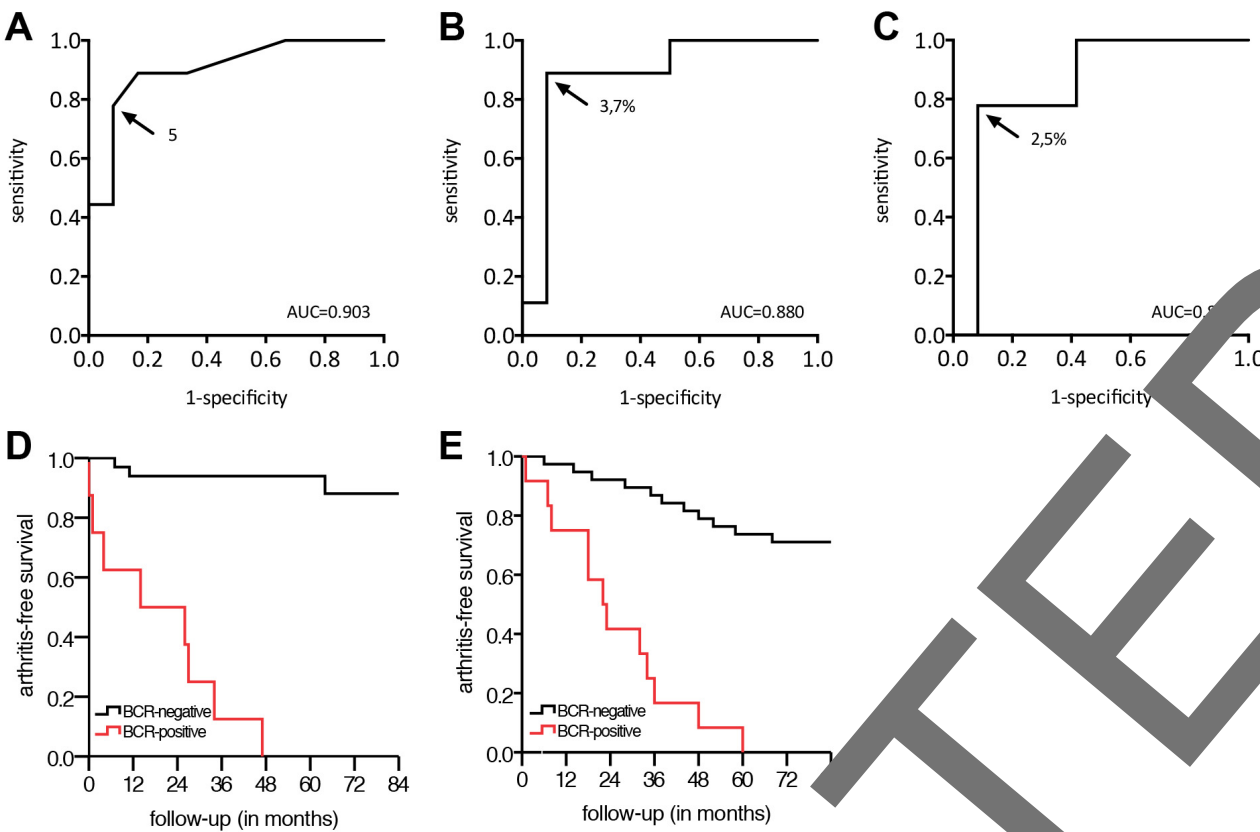

$\mathbf{F}$

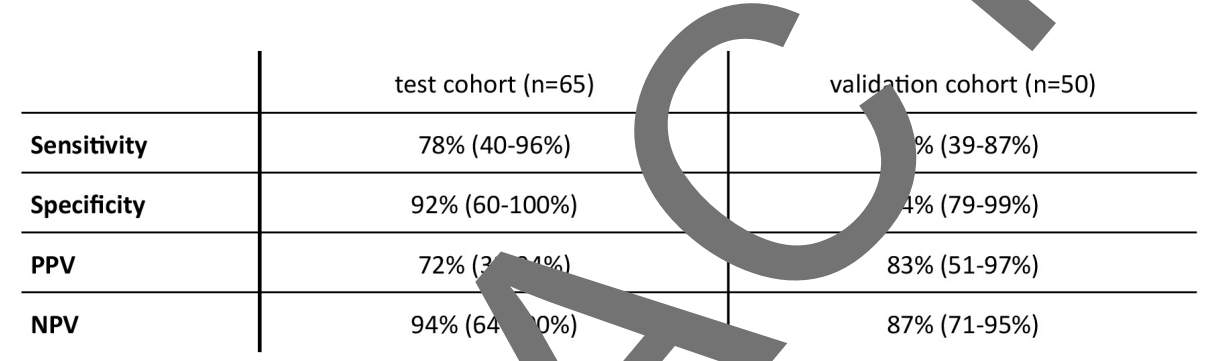

Figure 2 Receiver operating characteristic curves for (A) the numbe $f d$ nant clones, $(B)$ the impact of all dominant clones combined and (C) the impact of the most dominant clone in at-risk in - development of arthritis was analysed after 36 months of follow-up. The arrow points to the cut-off value chosen, and th -orres ding valu shown. (D) Kaplan-Meier curve for BCR-clone positive and BCR-Clone

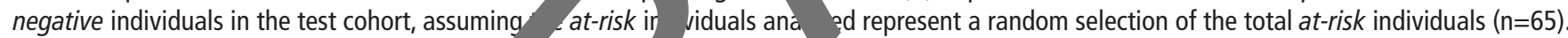
(E) Kaplan-Meier curve for $B C$-clone positive a $B C$-clon PPV and NPV including 95\% Cls for the BCR-Clo nodel. the test curvit and the validation cohort. AUC, area under the curve; BCR, B-cell receptor; NPV, negative predictive value; PPV, posit predica , sue.

We designed three tests bas on th umber of dominant BCR clones present, the impact $\mathrm{O}$. all domis clones combined on the BCR repertoire and impact of the most dominant BCR clone; ROC cur are depicted in figun A-C. Based on these ROC curves, mal cut- ${ }^{\prime} f_{s}$ were determined at $\geq 5$ dominant BCR clones aripher lood, a combined impact $\geq 3.7 \%$ and an impact of most minant $c^{d} \mathrm{e} \geq 2.5 \%$, respectively. We decided to use th sence of dominant BCR clones as comprehe nd intu 'mar' for further studies. This is further noted 'BCR-clo ative,' and $<5$ dominant $\mathrm{BCR}$ clone is 'BCR-c re negative, and collectively as the BCR-clone $m e$ Thu -0 f $1 \geq 5$ $\geq 5$ dominant clones in peripheral blood resulted in two ch distinguishable groups, and corresponding sensitivity of $78 \%$ ecificity of $92 \%$, positive predictive value (PPV) of $72 \%$ and neg e predictive value (NPV) of $94 \%$ (figure 2D, $2 \mathrm{~F}$ for the Kaplan-Meier curve, log rank test $\mathrm{p}<0.001)$. We had access to a second independent cohort of 50 subjects to validate our findings using the same cut-off value. Fifteen at-risk individuals developed arthritis within 36 months; the characteristics are described in table 2.

Analysis in this validation cohort showed that BCR-clone positive at-risk individuals had an $83 \%$ risk of developing RA within 36 months (PPV), while this risk was $13 \%$ in at-risk $B C R$-clone negative individuals (1-NPV), resulting in a relative risk of $6.3(95 \%$ CI 2.7 to $15, \mathrm{p}<0.0001, \log$ rank test $\mathrm{p}<0.001$, figure $2 \mathrm{E}$ ). Post hoc analysis on both cohorts revealed that within 60 months, all BCR-clone positive individuals developed arthritis (after 47, 48 and 60 months, respectively, online supplementary figure $\mathrm{S} 1$ ).

The 50 at-risk individuals in the validation cohort were previously used to develop a prediction model for the development of $\mathrm{RA},{ }^{24}$ the risk rule model. This describes a composite score of multiple clinical parameters categorising at-risk individuals into low, intermediate and high-risk individuals (respectively 17, 20 and 13 individuals). Using logistic regression analysis to calculate the added value of the BCR-clone model to the existing risk rule, an overall relative risk of 5.0 (95\% CI 1.2 to $20, \mathrm{p}=0.024)$ was found. In the low, intermediate and high-risk groups the relative risk contributed by BCR-clone positivity was estimated at 18 (95\% CI 0.6 to 520$), 6.1$ (95\% CI 1.9 to 20$)$ and $1.2(95 \%$ CI 0.6 to 2.7$)$, respectively.

In conclusion, we show that at-risk individuals with five or more dominant BCR clones in peripheral blood have an $83 \%$ risk of developing arthritis within 36 months, compared with a risk of $13 \%$ in individuals with four or less dominant BCR 


\begin{tabular}{|c|c|c|}
\hline & $\begin{array}{l}\text { At-risk individuals } \\
\text { no arthritis } \\
\text { developed ( } n=35 \text { ) }\end{array}$ & $\begin{array}{l}\text { At-risk individuals } \\
\text { arthritis developed } \\
(n=15)\end{array}$ \\
\hline Female sex, n (\%) & $22(63)$ & $8(53)$ \\
\hline Age, years, median (IQR) & $51(43-55)$ & $47(37-52)$ \\
\hline IgM-RF positive, n (\%) & $28(80)$ & $11(73)$ \\
\hline Level low positive, $n(\%)^{*} \dagger$ & $20(57)$ & $7(64)$ \\
\hline Level high positive, $n(\%)^{*} \dagger$ & $15(43)$ & $4(36)$ \\
\hline ACPA positive, $n(\%)$ & $20(57)$ & $14(93)$ \\
\hline Level, median $(I Q R)^{\star} \ddagger$ & $1333(364-9650)$ & $342(155-1016)$ \\
\hline $\begin{array}{l}\text { IgM-RF/ACPA double positive, } \\
\text { n (\%) }\end{array}$ & $13(37)$ & $10(67)$ \\
\hline ESR, median (IQR)§ & $12(4-18)$ & $10(3-19)$ \\
\hline CRP, median (IQR)ף & $2.4(0.9-4.5)$ & $2.3(1.1-9.4)$ \\
\hline 53TJC, median (IQR) & $0(0-0)$ & $0(0-1)$ \\
\hline \multicolumn{3}{|l|}{ Risk rule model $^{* *}$} \\
\hline Low risk, $n$ (\%) & $17(49 \%)$ & $0(0 \%)$ \\
\hline Intermediate risk, n (\%) & $14(40 \%)$ & $6(40 \%)$ \\
\hline High risk, $n(\%)$ & $4(11 \%)$ & $9(60 \%)$ \\
\hline
\end{tabular}

Positive lgM-RF: $>12.5 \mathrm{kU} / \mathrm{L}$.

Positive anti-CCP2 $>25 \mathrm{kAU} / \mathrm{L}$.

*Only in individuals who were positive.

†Levels were categorised into high/low positive according to cut-off levels used in the 2010 ACR/EULAR criteria for rheumatoid arthritis because of changed reference values over time.

$\ddagger$ Measured in $\mathrm{KAU} / \mathrm{L}$.

$\S$ Measured in $\mathrm{mm} /$ hour.

१Measured in $\mathrm{mg} / \mathrm{L}$.

**Score based on the risk rule ${ }^{24}$ scaled 0-13 points.

ACPA, anticyclic citrullinated peptide antibodies (using anti-CCP2 test); CRP

C-reactive protein; ESR, erythrocyte sedimentation rate; IgM-RF, rheumatoid factor

the IgM isotype; 53TJC, tender joint count assessed in 53 joints. clones. Moreover, analysis after 5 years re aled that individ-
uals who initially tested positive develops thritic

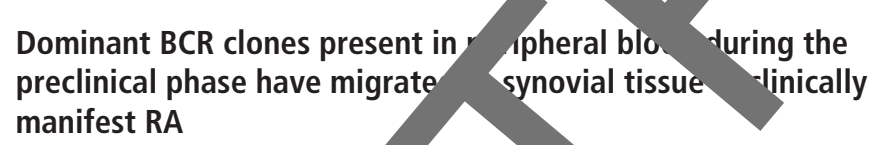

We hypothesised that if the oserved a inant BCR clones are involved in synovial infl mation, then th clones might also be detectable in synoy cissue after onset of $\mathrm{T}$ To this end, we analysed peripheral ood sam "s obtained during the preclinical stage, and $\mathrm{p}$ ed blood ad synovial tissue after onset of arthritis in eight in idua who devel ed arthritis.

Up to $29.3 \%$ (mo IQR 9. $45.8 \%$ ) of all preclinically dete domina nerip al blood BCR clones were detecta in sy vial tiss. er development of arthritis. All $r$ red with the top 25 most dominant clones in synovia sue (fig strikingly, none of the preclinically ect dominant peripheral blood BCR clones could be recon from peripheral blood after arthritis developed (figure 3B,C, ditional analyses of the dominant clones found in both periphe. blood and synovial tissue showed that these clones are class switched to the IgG1 isotype and enriched for IGHV4-34, features that are all associated with autoreactivity, while IGHV3-23, IGHV1-69, CDR3 length, ACPA or IgM-RF titres, and HLA-DRB1 shared epitope positivity (SE) are comparable between the three groups (described in online supplementary results, supplementary figures 2 and 3, and supplementary table 2). ${ }^{30-33}$
Together, these analyses show that dominant BCR peripheral blood clones present during the preclinical phase of arthritis are in part retrievable as dominant clones in synovial tissue once arthritis becomes clinically apparent. At this time point, the clones are no longer found in peripheral blood anymore. These migratory clones have features that have been associated with autoreactivity.

\section{DISCUSSION}

The results presented here show th the presence of minant BCR clones in peripheral blood prea, with high accl cy the onset of arthritis in patients y are an of devel ng RA. Moreover, we found supp that these do nant ones may migrate to synovial tissue ce arthrit becomes arent. These findings are consistent the no that B-cell abnormalities occur up to several yea efor ne onset synovial inflammation, and that develo nt of RA multistep process. Conceivably, a ' ond hit,' for tance crauma or viral infection, may lea vnovial inflam, subsequent migration of autorear $\mathrm{B}-\mathrm{B}$ lones towards tne synovium and impaired resolution of inflamm. $\eta$ in patients with pre-existing systemic autoimmunity. $^{2}{ }^{34}$ This provides the rationale for future stu-cell abnormal s during the preclinical stage in 9 or immune-mediated inflammatory diseases like systemic bus erythemate (SLE), multiple sclerosis (MS) and type diabetes (T1D), id opens up the perspective of preventive ii vention.

S. not all dividuals with RA-specific antibodies progress to manifest RA, the relation between RA-specific mtibodies and clonal expansions is unclear. The current data more that the antibodies in the preclinical phase are roducea by plasmablasts and long-lived plasma cells located elsewhere (eg, bone marrow and spleen), ${ }^{35}$ and B cells and plasmablasts present in blood represent migrating cell populations. Moreover, better biomarkers are needed to predict which at-risk individuals will develop RA. Autoantibody and cytokine profiles, specific gene signatures, body mass index, current smoking and autonomic nervous system dysfunction all contribute to the risk of developing RA. ${ }^{36-41}$ Our data provide a novel biomarker that has superior predictive power compared with other available biomarkers evaluated so far. It increases the accuracy of the previously reported prediction rule for the development of arthritis in autoantibody positive subjects. ${ }^{24}$

Identification of at-risk individuals who will develop RA in the short term enables development of early preventive strategies. ${ }^{29}$ Our findings support the rationale for B cells or the interaction between B cells and T cells as targets for preventive therapy. The cut-off used here (five or more dominant clones) was chosen to be able to identify subjects with a high risk of developing RA with an acceptable NPV to avoid unnecessary treatment. Whether a preventive pharmacological intervention will be considered acceptable is of course dependent on the benefit/risk profile and the cost-effectiveness of the specific treatment.

As discussed above, there is strong evidence for a role of $\mathrm{B}$ cells and plasma cells in the pathogenesis of RA. The development of RA is associated with defects in central and peripheral tolerance leading to autoreactive $\mathrm{B}$ cells, ${ }^{43}$ and circulating autoantibodies can be detected years before the onset of the disease. It is tempting to speculate that the clones identified in the present study are pathogenic B cells since (1) they are not detected in healthy controls nor in subjects at risk who do not develop RA after follow-up, (2) their dominance suggests 

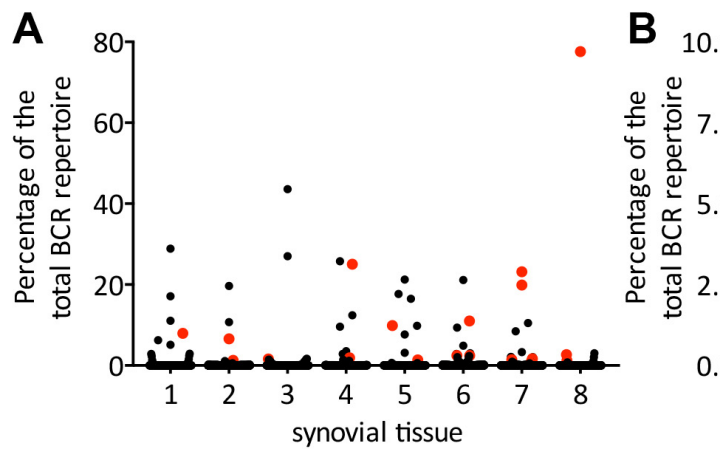

\section{C}

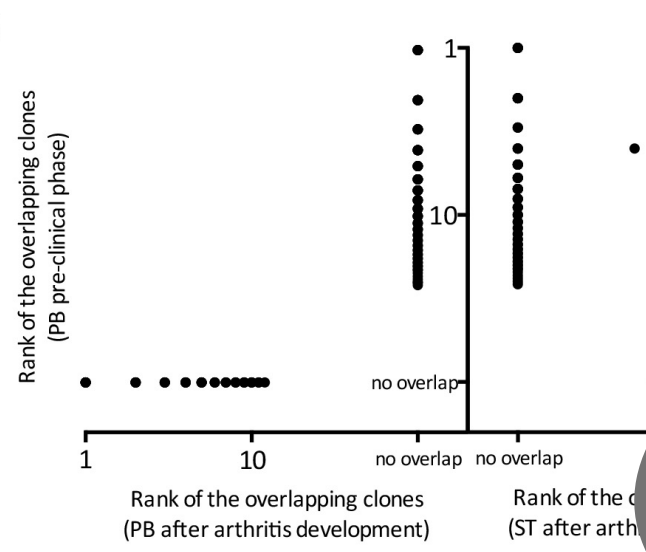

Figure 3 Scatterplot of the BCR repertoire in synovial tissue $(A)$ and periphera represents one clone. Clones in red represent clones that were dor inantly present in clones is depicted as percentage of the total $\mathrm{BCR}_{\text {heavy }}$ sequences. ( phase and after arthritis development $(n=8)$. The $y$-axis depicts the $k$ of the pooled). On the left x-axis the overlap with dominant clones in perip al bl dominant clones in synovial tissue after arthritis develonmont. In case $\mathrm{PB}$, peripheral blood; ST, synovial tissue.

activity, (3) the clones seem to migrat

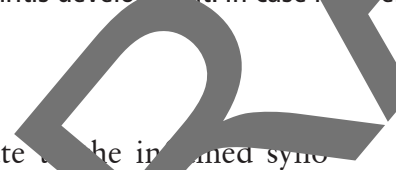
vial tissue after arthritis developmen and (4) clones show additional features associated wity atoreactivity

There are technical limitatio the study; first, measure the $\mathrm{BCR}_{\text {heavy }}$ chain repertoire mi level since it only identifies expressed BCRs and hunits the mer of amplifications. However, we cannot di gguish whether signatures are derived from memory cells or plasma cells. evertheless, the presence of dominz $B C R$ clo $s$ in the preclinical phase of RA is a robust and re ducible rker. Second, to analyse mRNA, cells were lysed vent further enotypic characterisation of dominant clo urther u velling the phenotype of BCR clon prech $1 \mathrm{pha}$ is essential to better understand $t^{1}$ iole $\mathrm{or}$ ese cells earliest phase of disease, and migh cad to es 1 more specric biomarkers. Third, coupling of heavy ins is prevented by the technique used, ating determination of reactivity. This should be addresse future study.

All patien d clinically manifest arthritis at the time of the second synovia psy but the joint that was biopsied was not clinically inflamed except for one patient. Still, these biopsies showed a diverse repertoire resembling the repertoires of clinically inflamed joints, containing the dominant predictive BCR clones identified in peripheral blood in the preclinical phase. This can be explained by the fact that clinically uninvolved joints of patients with established RA exhibit histological signs of synovial inflammation, as described before. ${ }^{44}$
Taken together, we show the presence of increased BCR clonal signatures in peripheral blood obtained during the preclinical stage of RA. During onset of arthritis, these BCR clones disappear from blood and appear in the target tissue, where they may drive autonomous disease progression. Our observations show that the presence of dominant BCR clones in peripheral blood in the at-risk stage accurately predicts short-term onset of clinically manifest disease. Consequently, they may serve as a biomarker that could help guide decisions about pharmacological treatment to prevent the onset of clinically manifest disease. This is important since recent studies clearly indicate that early intervention may be more effective and lead more often to drug-free remission. ${ }^{45}$ There are already studies that focus on intervention during the pre-RA phase. An example is the recently completed "PRAIRI" study (http:// www.trialregister.nl/trialreg/ admin/rctview.asp?TC=1969), in which individuals at risk of developing RA were treated with a single course of rituximab to delay development of clinically manifest arthritis. The current marker determined during the preclinical phase can be used to further investigate the effect of therapeutical intervention on the clonal distribution over time. Similar studies are currently under way with abatacept and simvastatin. Future work should explore whether BCR clones might also predict onset of disease in other immune-mediated inflammatory disorders like type 1 diabetes, multiple sclerosis, SLE and vasculitis. 
Acknowledgements We would like to thank Rebecca Esveldt, Barbera van Schaik, Marja Jakobs, Ted Bradley and Dr Lisa van Baarsen for technical assistance. This work was carried out on the Dutch national e-infrastructure with the support of SURF Foundation. Parts of this work have been presented at a scientific meeting and/or published as a conference abstract.

Contributors All authors contributed to the formulation of the hypotheses and research questions and the analysis plan, and provided critical input into the draft manuscript. PPT, MJHdH, MHvBT, DVS and DMG were involved in recruitment of patients to the study. MED and PLK performed the experiments under supervision of PPT, FB and NdV. MED, MJHdH, PLK, AHCVK and NdV did the statistical analysis. PPT, MED and NdV drafted the manuscript.

Funding This study was partially supported by the Dutch Arthritis Association (grant no 06-1-303). MED, NdV, DMG and PPT received support from CTMM, the Center for Translational Molecular Medicine, project TRACER (grant 04I-202), and BTCURE, a research project from the Innovative Medicines Initiative Joint Undertaking (grant no 115142-2). PLK was supported by an AMC Graduate School PhD Scholarship.

Competing interests None declared.

Ethics approval Academic Medical Center/University of Amsterdam and MC Slotervaart Amsterdam, The Netherlands.

Provenance and peer review Not commissioned; externally peer reviewed.

Open Access This is an Open Access article distributed in accordance with the Creative Commons Attribution Non Commercial (CC BY-NC 4.0) license, which permits others to distribute, remix, adapt, build upon this work non-commercially, and license their derivative works on different terms, provided the original work is properly cited and the use is non-commercial. See: http://creativecommons.org/ licenses/by-nc/4.0/

(c) Article author(s) (or their employer(s) unless otherwise stated in the text of the article) 2017. All rights reserved. No commercial use is permitted unless otherwise expressly granted.

\section{REFERENCES}

1 Nielen MM, van Schaardenburg D, Reesink HW, et al. Specific autoantibodies precede the symptoms of rheumatoid arthritis: a study of serial measurements in bloo donors. Arthritis Rheum 2004;50:380-6.

2 van de Sande MG, de Hair MJ, van der Leij C, et al. Different stages of rheumato arthritis: features of the synovium in the preclinical phase. Ann Rheum Dis 2011;70:772-7

3 de Hair MJ, van de Sande MG, Ramwadhdoebe TH, et al. Featur individuals at risk of developing Rheumatoid arthritis: implic preclinical rheumatoid arthritis. Arthritis Rheumatol 2014

4 Berger T, Rubner P, Schautzer F, et al. Antimyelin antibe clinically definite multiple sclerosis after a first demy 2003:349:139-45.

5 Wasserfall $\mathrm{CH}$, Atkinson MA. Autoantibody m of type 1 diabetes. Autoimmun Rev 2006:5;

6 Eriksson C, Kokkonen $\mathrm{H}$, Johansson M, et utoantibodies predate onset of systemic lupus erythematosus in nortb sh Arthritis Res Ther 20, 3:R30.

7 van Schaik FD, Oldenburg B, Hart A al. Sero, markers predict inflammatory bowel disease years before the diagrosis. Gut 2013, $3-8$.

8 Aho K, Heliövaara M, Maatel? t al. Rheumatoid facto, edating clinical rheumatoid arthritis. J Rhe, ol 1991;18:1282-4.

9 Rantapää-Dahlqvist S, d ig BA, Berglin E, et al. Antibodies against cyclic citrullinated peptide gA rheumat actor predict the development of rheumatoid arthrit thritis Rhey 003:48:2741-9.

10 van der Woude D, Rà ä-Dar st S, loan-Fac A, et al. Epitope spreading of the anti-citrullinated pr.tibody respor sccurs before disease onset and is ass vith the dis course of arthritis. Ann Rheum Dis van radt $L A$, va er Horst $A R$, at ng MH, et al. The extent of the anti 1 van radt $\mathrm{LA}$, va er Horst $\mathrm{AR}$, at ing $\mathrm{MH}$, et al. The extent of the antionts with se Ann Rheum Dis 2011;70:128-33.

12 De $\mathrm{YD}, \mathrm{O}^{\prime}$ nell $\mathrm{Cl}$, Hueber $\mathrm{w}$, et al. The number of elevated cytokines and chemo. preclinical seropositive rheumatoid arthritis predicts time to diagnosis in an age- dent manner. Arthritis Rheum 2010;62:3161-72.

13 Kokkonen $\mathrm{H}_{\text {, J }}$ tröm I, Rocklöv J, et al. Up-regulation of cytokines and chemokines preda. ie onset of rheumatoid arthritis. Arthritis Rheum 2010;62:383-91.

14 Schellekens GA, Visser $H$, de Jong BA, et al. The diagnostic properties of rheumatoid arthritis antibodies recognizing a cyclic citrullinated peptide. Arthritis Rheum 2000;43:155-63.

15 Bos WH, Wolbink GJ, Boers M, et al. Arthritis development in patients with arthralgia is strongly associated with anti-citrullinated protein antibody status: a prospective cohort study. Ann Rheum Dis 2010;69:490-4.
16 Schellekens GA, de Jong BA, van den Hoogen FH, et al. Citrulline is an essential constituent of antigenic determinants recognized by rheumatoid arthritis-specific autoantibodies. J Clin Invest 1998;101:273-81.

17 Tak PP, Smeets TJ, Daha MR, et al. Analysis of the synovial cell infiltrate in early rheumatoid synovial tissue in relation to local disease activity. Arthritis Rheum 1997:40:217-25.

18 Vossenaar ER, Smeets TJ, Kraan MC, et al. The presence of citrullinated proteins is not specific for rheumatoid synovial tissue. Arthritis Rheum 2004;50:3485-94.

19 Edwards JC, Szczepanski L, Szechinski J, et al. Efficacy of B-cell-targeted therapy with rituximab in patients with rheumatoid arthritis. N Ena' 50:2572-81.

20 Doorenspleet ME, Klarenbeek PL, de Hair MJ, et al cumatoid an. synovial tissue harbours dominant B-cell and plasma-cell nes associated with oreactivity. Ann Rheum Dis 2014;73:756-62.

21 Gerlag DM, Raza K, van Baarsen LG, et al. EULr ommendations for te nology and research in individuals at risk of $\mathrm{Rb}$-matoid ar report from th ady group for risk factors for rheumatoid ritis. Ann Rhem 2012;71 s-41.

22 Aletaha D, Neogi T, Silman AJ, et ? 10 Rheumatoid arth ' an American College of Rheum collaborative initiative. Arthr ogy/Europea ague agains amatism heum $2010,2569-81$.

23 Aletaha D, Neogi T, Silman As, 2010 amatoid arthri classification criteria: an American College $o$ speuman League inst Rheumatism collaborative initiati

24 van de Stadt LA BI, Bos WH, et al. dictir are for the development of arthritis in ser arthralgia patients. An Dis 2013;72:1920-6.

25 van de San ,G, G DM, Lodde BM, et al. -valuating antirheumatic treatments using syru al biopsy: a mendation for standardisation to be used in clinical trials. Ann Rheum Dis 2011, 3-7.

26 Klara 1 PL, de Hair MJ, Dooro Me, et al. Inflamed target tissue provides a e for highly expanded T-n clones in early human autoimmune disease. ann Rheum Dis 2012:71:1088-93.

Klarenbeek PL, Tak an Schaik BD, et al. Human T-cell memory consists mainly of unexpanded clones. $\mathrm{h}$ unol Lett 2010;133:42-8.

Giudicelli V, Chaume efranc MP. IMGT/GENE-DB: a comprehensive database for man and mouse ir anoglobulin and T cell receptor genes. Nucleic Acids Res 3:D256-6:

29 Gerlay SM, Tak PP. Towards prevention of autoantibody-positive rheumatoid arthritis: from lifestyle modification to preventive treatment. matology 2016;55:607-14.

$A$, Greiner A, Seyfert C, et al. Differentiation of B cells in the nonlymphoid tissue of the synovial membrane of patients with rheumatoid arthritis. Proc Nat/ Acad Sci U SA 1996;93:221-5

31 Pugh-Bernard AE, Silverman GJ, Cappione AJ, et al. Regulation of inherently autoreactive VH4-34 B cells in the maintenance of human B cell tolerance. J Clin Invest 2001;108:1061-70.

32 Wardemann $\mathrm{H}$, Yurasov $\mathrm{S}$, Schaefer A, et al. Predominant autoantibody production by early human B cell precursors. Science 2003;301:1374-7.

33 Cambridge G, Moura RA, Santos T, et al. Expression of the inherently autoreactive idiotope $9 \mathrm{G} 4$ on autoantibodies to citrullinated peptides and on rheumatoid factors in patients with early and established rheumatoid arthritis. PLoS One 2014;9:e107513.

34 Buckley CD, Gilroy DW, Serhan CN, et al. The resolution of inflammation. Nat Rev Immunol 2013:13:59-66.

35 Manz RA, Thiel A, Radbruch A. Lifetime of plasma cells in the bone marrow. Nature 1997:388:133-4.

36 van Baarsen LG, Bos WH, Rustenburg F, et al. Gene expression profiling in autoantibody-positive patients with arthralgia predicts development of arthritis. Arthritis Rheum 2010;62:694-704.

37 Sokolove J, Bromberg R, Deane KD, et al. Autoantibody epitope spreading in the preclinical phase predicts progression to rheumatoid arthritis. PLoS One 2012;7:e35296.

38 Lübbers J, Vosslamber $S$, van de Stadt LA, et al. B cell signature contributes to the prediction of RA development in patients with arthralgia. Ann Rheum Dis 2015;74:1786-8

39 de Hair MJ, Landewé RB, van de Sande MG, et al. Smoking and overweight determine the likelihood of developing rheumatoid arthritis. Ann Rheum Dis 2013;72:1654-8.

40 Koopman FA, Tang MW, Vermeij J, et al. Autonomic dysfunction precedes development of Rheumatoid arthritis: a prospective cohort study. EBioMedicine 2016;6:231-7.

41 Moura RA, Cascão R, Perpétuo I, et al. Cytokine pattern in very early rheumatoid arthritis favours B-cell activation and survival. Rheumatology 2011;50:278-82.

42 Tak PP. Are we ready to change the pace of arthritis treatment? treating pre-arthritis and very early arthritis. Acta Reumatol Port 2011;36:8-9.

43 Samuels J, Ng YS, Coupillaud C, et al. Impaired early B cell tolerance in patients with rheumatoid arthritis. J Exp Med 2005:201:1659-67.

44 Kraan MC, Versendaal H, Jonker M, et al. Asymptomatic synovitis precedes clinically manifest arthritis. Arthritis Rheum 1998:41:1481-8.

45 Raza K, Saber TP, Kvien TK, et al. Timing the therapeutic window of opportunity in early rheumatoid arthritis: proposal for definitions of disease duration in clinical trials. Ann Rheum Dis 2012;71:1921-3. 


\section{Retraction: Dominant B cell receptor clones in peripheral blood predict onset of arthritis in individuals at risk for rheumatoid arthritis}

Paul Peter Tak, Marieke Doorenspleet, Marjolein de Hair, Paul Klarenbeek, Marian van Beers-Tas, Antoine van Kampen, Dirk Jan van Schaardenburg, Danielle Gerlag, Frank Baas, Niek de Vries.

This article has been retracted.

The editors of Ann Rheum Dis have been notified by Professor Paul Peter Tak and Professor Niek de Vries of the Amsterdam University Medical Center, Amsterdam, The Netherlands that they and the other authors of the above article wish to retract the paper.

The authors state:

During follow-up studies to advance our insights into the role of B cell clones during the earliest stage of rheumatoid arthritis (RA), we observed that we could not detect some of the clones that we previously described in subjects at risk of developing RA. After subsequent review of the original data published in Ann Rheum Dis 2017;76(11):1924-1930, we detected errors in assignment of clinical data to sequencing data. As a result, we cannot support the conclusions of the article anymore and we wish to retract the publication. Further investigation into the source of the error is ongoing. We communicate our sincere apologies.

Related publications affecting this retraction:

- Tak PP, M.E. Doorenspleet, M.J.H. de Hair, P.L. et al. Dominant B-cell receptor clones in peripheral blood predict onset of arthritis in individuals at risk for rheumatoid arthritis [Abstract 08.21]. European Workshop for Rheumatology Research March fourth 2017, Athens, Greece. Ann Rheum Dis 2017; 76 (Suppl 1); A83. https://ard.bmj.com/content/ 76/Suppl_1/A83.2

- Tak PP, Doorenspleet ME, de Hair M, et al. Dominant B-Cell Receptor Clones in Peripheral Blood Predict Onset of Arthritis in Individuals at Risk for Rheumatoid Arthritis [abstract OP0173]. EULAR 2017, Madrid, Spain. Ann Rheum Dis 2017; 76 (Suppl 2):124.

- Musters A, van Beers-Tas MH, Doorenspleet ME, et al. Dominant B cell receptor clones in peripheral blood predict onset of arthritis in individuals at risk for Rheumatoid Arthritis a validation cohort. Abstract OP0204. Ann Rheum Dis, volume 77 Suppl 2, 2018, A151. Further information may be available from the authors.

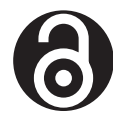

\section{OPEN ACCESS}

Open access This is an open access article distributed in accordance with the Creative Commons Attribution Non Commercial (CC BY-NC 4.0) license, which permits others to distribute, remix, adapt, build upon this work noncommercially, and license their derivative works on different terms, provided the original work is properly cited, appropriate credit is given, any changes made indicated, and the use is non-commercial. See: http://creativecommons.org/licenses/by-nc/ 4.0\%.

(c) Author(s) (or their employer(s)) 2021. Re-use permitted under CC BY-NC. No commercial re-use. See rights and permissions. Published by BMJ.

Ann Rheum Dis 2021;80:e139. doi:10.1136/annrheumdis-2017-211351ret

Check for updates 